\title{
A Combined GIS, Remote Sensing And Geophysical Methods For Groundwater Potential Assessment Of Ilora, Oyo Central, Nigeria
}

Olubukola Ogungbade

Olabisi Onabanjo University

Stephen Oluwafemi Ariyo

Olabisi Onabanjo University

Sodiq Abiodun Alimi ( $\nabla$ alimi.sodiq@gmail.com )

University of Ilorin Faculty of Science https://orcid.org/0000-0002-9013-754X

Vincent Cephas Alepa

University of Ilorin

Saheed Akinwumi Aromoye

University of Ilorin

Oluwafemi Joseph Akinlabi

Nigeria Hydrological services agency

\section{Research Article}

Keywords: Aeromagnetic, Weighted Overlay, AHP, Landsat 8 OLI, ASTER DEM, Basement Complex, Groundwater Exploration

Posted Date: July 15th, 2021

DOl: https://doi.org/10.21203/rs.3.rs-267236/v1

License: (c) (i) This work is licensed under a Creative Commons Attribution 4.0 International License.

Read Full License

Version of Record: A version of this preprint was published at Environmental Earth Sciences on January 25th, 2022. See the published version at https://doi.org/10.1007/s12665-022-10199-x. 


\section{Abstract}

This research combined GIS, Remote sensing and geophysical methods for groundwater potential investigation. The study aimed at delineating groundwater potential zones within Ilora, Oyo central, Nigeria. Unavailability of water is a major menace in these area and agricultural activities are suffering as a result. Landsat 8 OLI, ASTER DEM, geological, geophysical, and soil data of the research area were acquired for this study. In order to map groundwater potential of the area, eight thematic layers that influence groundwater occurrences and movement controlling factors such as, geology, elevation, slope, land use land cover (LULC), fault proximity, soil, lineament density, and drainage density were mapped out from the acquired data of the area. The influence of each theme and sub unit/class to groundwater recharge based on previous studies was evaluated using Analytical Hierarchical Process (AHP). The groundwater potential of the area of study was qualitatively classified into five classes, namely; very high, high, moderate, low, and very low which account for $0.3 \%, 7.8 \%, 54.8 \%, 35.6 \%$, and $1.5 \%$ of the total area respectively. The results were cross-validated using well data from the area and $89 \%$ correlation was achieved. The groundwater potential map generated in this research could be used as a preliminary reference in selecting suitable sites for groundwater resource exploitation in the area in order to ameliorate the current scarcity of water in this region.

\section{Introduction}

Water, for many years, has been one of the most important resource that humans need to survive. While it exists in abundance in some areas, it remains a scarce commodity in others due to various geogenic and anthropogenic factors. Nigeria, like many west African countries, has two season; dry season in which rainfall is scarce and raining season in which rainfall is abundant. However, the duration of these seasons varies across cities in the country. Lack of rainfall results in exhaustions of surface water and consequently water scarcity. This has led to over reliance on groundwater for many domestic and agricultural activities in the country.

The geology of Nigeria is made up of three major geological components, they are; the basement complex, younger granites, and the sedimentary basins (Obaje 2009). The presence of favourable porosity and permeability within the sedimentary basins of Nigeria makes it easy for groundwater recharge and accumulation, hence groundwater occurs in appreciable quantity in areas located within the sedimentary basins. The basement complex geology is a bit more complex compared to the sedimentary terrains. Groundwater is hard to come by in these areas due to the impervious nature of the basement rocks.

Within the Basement complex terrain of Nigeria, groundwater is said to be abundant in areas where thick overburden overlies a fractured basement (Olasehinde 1999). Some of the problems encountered by groundwater development in many parts of Nigeria include the non-uniform, discontinuity, and complexities of the aquifer systems in the crystalline basement rocks which result in well/borehole dry ups (Hazell et al. 1992). Other obstacles encountered include lack of data, equipment, methods, and 
manpower which would have aided the identification of the promising high yield well/borehole sites (Boeckh 1992; Offodile 2002; Badamasi, et al. 2016). Groundwater exploration in Nigeria is still traditional and improvement in the needed technology is slow paced, therefore, there is need for cost effective, accurate, and technologically appropriate solutions to groundwater exploration in the country (Tarhule 2007; Badamasi et. al. 2016).

Geographic information system and Remote Sensing on their own have proven to be a very strong tool in groundwater exploration. Various GIS techniques have been used for groundwater potential zone delineation. They have proven to be useful in Analytical Hierarchical Process (AHP) (Badamasi et al. 2016), Multi Influence Factor Analysis (Das et al., 2018), Fuzzy Logic Analysis (Tiwari et al. 2017), and Multi-criteria decision analysis (MCDA) (Senanayake et al. 2015; Hussein et al. 2017) etc.

Geophysics for many years have provided useful remote and ground trothing techniques for groundwater studies. There are different types of geophysical methods; gravity, magnetic, seismic, electrical, radiometry etc. Electrical resistivity method has been one of the most popular geophysical methods in groundwater studies due to its ability to identify groundwater signatures using contrasts in electrical resistivity of the subsurface materials (Loke, 2013). The magnetic method is probably the most versatile of all the geophysical methods (Dobrin and Savit 1988) because it can be applied to both shallow and deep seated targets. Magnetic method has emerged a powerful tool in groundwater prospecting in recent years due to its ability to reveal lineaments (folds, faults, joints and fractured zone) which may serve as openings for groundwater accumulation and storage (Oni et al, 2020; Abdulkareem et al. 2018; Muthamilselvan et al. 2017; Al-Gharni 2005). The advancement in magnetic data acquisition and processing have made it easy for its usage in a GIS environment (Oni et al, 2020). Derivative maps of Aeromagnetic data can now be added as a thematic layer together with other layers derived from various datasets for a more accurate groundwater potential zone delineation.

The ability to integrate various datasets for groundwater studies will most likely yield a better result in delineating groundwater potential zones within the basement complex terrain of Nigeria. Research integrating geophysical, GIS and RS datasets are uncommon and as such, the purpose of this present study is to delineate groundwater potential zones in Ilora, Oyo central using advance geospatial techniques.

\section{Study area description}

The present area of study falls in between two local governments of Oyo central senatorial district, Oyo west and Afijio, Oyo state, Nigeria (Fig. 1). It is situated between latitudes $7^{\circ} 46^{\prime} \mathrm{N}$ to $7^{\circ} 55^{\prime} \mathrm{N}$ and longitudes $3^{\circ} 45^{\prime} \mathrm{E}$ to $3^{\circ} 55^{\prime} \mathrm{E}$ covering an area of approximately $245 \mathrm{~km}^{2}$.

Mean annual rainfall in the study area ranges from 1,117.1 to $1,693.3 \mathrm{~mm}$ (Daramola et al. 2019). Rainfall pattern in this area has a characteristic bimodal distribution that mostly peaks around June or July and September and period of low precipitation occurs around August with four months of dry season (December - March) (Daramola et al. 2019). Annual temperature ranges from of $24.6^{\circ} \mathrm{C}$ and 
$31.5^{\circ} \mathrm{C}$ (Nimet 2019). Mean monthly relative humidity reaches a minimum of $52 \%$ in February and a maximum of $83 \%$ in August (Daramola et al. 2019; Erakhrumen 2008).

The area of study is well-drained with rivers flowing from the upland to the low land in an east-west direction (Daramola et al. 2019). Elevation ranges between $151 \mathrm{~m}$ in the west and $352 \mathrm{~m}$ above sea level in the east. The climate and vegetation of the area favours the cultivation of cash crops such as yam, beans, maize, cassava, plantain and rice primarily but also some tree crops including cocoa, oil palm, cashew as well as a number of other cash crops. Occupation of the inhabitants of the study area is mostly farming which is supported by a number of government agricultural farm settlements in the area.

Geologically, the present area of study falls within the basement complex of south western Nigeria, basement rocks that underlie the llora and environs include migmatite, quartzite, and schists which are Precambrian in age (fig.2). This geological formation is primarily highly impervious except where deeply weathered or fractured. Groundwater flow in hard rocks are usually controlled by factors such as fractures, joints, geological contacts, shear zones, faults, vugs, and other discontinuities, their multifaceted interrelationship controls overall aquifer dynamics (Singhal and Gupta 1999; Eaton et al., 2007).

\section{Materials And Methods}

This study made use of both primary and secondary data. The primary data consists of Landsat 8 OLI, ASTER Digital Elevation Model data retrieved from glovis.usgs.gov, and aeromagnetic data of the area retrieved from Nigerian Geological Survey Agency. The secondary data include geology, soil, and topographical maps of the study area derived from Nigerian geological survey agency and Center for World Food Studies. ArcGIS, Rockworks, ENVI, and PCI Geomatica Software were used for data processing.

\section{Data processing}

The ASTER DEM data was further processed to derive Elevation, Drainage density, and Slope maps of the area of research, Landsat 8 data was used to generate Land Use Land Cover and Lineament density maps, while the acquired aeromagnetic data was processed and used to produce the first vertical derivative map of the area. The first vertical derivative map (FVD) is a map of subsurface lineaments that underlies the area of research, these lineaments could be faults, folds, joint/fractures, lithological boundaries or rock contacts which may have been formed during orogenic activities, they are all significant in groundwater exploration studies. The FVD map was further used to produce the fault proximity map of the area which signifies closeness or farness of an area to a fault. Acquired geology and soil maps of the area were georeferenced and digitized while topographical map of the area was used to digitize the major roads, footpaths, and settlements present in the area of research.

\section{Thematic map preparation}


Further, eight thematic layers were developed from the acquired maps (Elevation, Drainage Density, Slope, Land use Land cover, Geology, Soil, Lineament Density, Fault proximity) using various software/tools; fault proximity map was extracted from first vertical derivative map of aeromagnetic data of the area of study using Oasis Montaj software, surface lineaments and land use/land cover maps were prepared from the Landsat 8 OLI/TRS data using ENVI, PCI Geomatica, ArcGIS software and Rockworks. Maximum likelihood classification was employed to produce land use/land cover map of the research area.

Elevation, drainage, and slope maps were extracted via Archydro tools in ArcGIS. In order to derive the thematic maps from the secondary data, hard copy maps (geology and soil) were scanned and imported into the ArcGIS software then georeferenced to World Geodetic System (WGS 84) coordinate system.

\section{Analytical Hierarchical Process}

Weighting of the thematic maps was carried out using the Analytical Hierarchical Process (AHP). Multi criteria decision analysis using Analytical Hierarchical Process (AHP) is the one of the most common and well known GIS based method for delineating groundwater potential zones (Arulbalaji et al., 2019). This method helps in integrating all thematic layers. 8 different thematic layers were used for this research, the thematic layers include slope, elevation, drainage density (DD), lineament density (LD), land use land cover (LULC), geology, fault proximity, and soil. The 8 thematic layers largely influence the flow and storage of water in the area. Weight assignment to these factors is based on groundwater occurrence within the basement cpmplex terrain of Nigeria and literature review of several researchers (Yeh et al., 2016; Bayowa et al., 2014; Fashae et al. 2014; Nampak et al., 2014; Rahmati et al., 2015; Olasehinde 1999; Olorunfemi and Fasuyi 1993). A parameter with high weight illustrates a layer with high impact and a parameter with a low weight illustrates a small impact on groundwater potential. The weightages of each parameter were assigned according to Saaty's scale (1-9) of relative importance value. Further, the weights were assigned with consideration of the review of past studies and field experience. The Saaty's scale of relative importance value reveals that value of 9 indicates extreme importance, 8 very strong, 7 very to extreme importance, 6 strong plus, 5 strong importance, 4 moderate plus, 3 moderate importance, 2 weak and 1equal importance (Saaty 1990). As per the classification, weights were assigned to the thematic layers based on their importance and water holding capacity.

The mapping of the groundwater potentials of the study area was done by weighted index overlay method in the ArcGIS 10.8. Weight assignment was done by assigning the new weight values to the maps' sub-units (sub criteria) computed from the AHP. The reclass tool in the spatial analyst tool of the ArcGIS 10.8 was used for this task. Groundwater potential zones map of the area of research was produced by overlaying all the thematic layers using the weighted index overlay tool. Figure 3 shows the flow chart of methodology for groundwater potential zone mapping of llora and environs.

Groundwater Potential Zone Map (GWPZ) $=\sum_{i, j=1}^{\&} W_{i} X_{j}$

Where; $W i=\%$ weight for each thematic map

$X j=$ reclassified map 


\section{Accuracy Assessment and Validation}

In order to validate the accuracy of the ground water potential that would be generated in this research, static water levels and well yield data were collected across drilled wells in the area. The yield of the wells would be used to validate the groundwater potential map while error matrix would be used for accuracy assessment. An error matrix is a square array of numbers set out in rows and columns which expresses the number of sample units (i.e., pixels, clusters of pixels, or polygons) assigned to a particular category relative to the actual category as verified by some reference data. The columns usually represent the reference data while the rows indicate the classification generated from the remotely sensed data. In other words, an error matrix is a comparison between sampled areas on the map generated from the remotely sensed data and those same areas as determined by some reference data (Congalton, 1991). An error matrix is not only used for accuracy assessment but also helps to enhance the accuracy of the output map (Doke et al. 2021).

\section{Results And Discussion}

Figure 3 above shows the eight thematic maps produced for ground water potential mapping of llora, each of these factors plays crucial role in the availability of groundwater in an area. The geology of an area is very vital in the occurrence and distribution of groundwater in that area (Yeh et al. 2016). The geology controls infiltration rate and flow of water into and out of rock formations. The published geological map of Oyo state (NGSA 2005) by the Nigerian Geological Survey Agency (NGSA) was used for delineating different geological units in the research area (Fig 2e). The present area of study situates within the Precambrian Basement Complex terrain of Nigeria as earlier stated, migmatite cover approximately $77 \%$ of the total area while banded gneiss and quartzite and schist occupies $16 \%$ and $5 \%$ respectively (Table 1). Based on evidence from drilled wells, quartzite and schist are usually highly fractured and tend to play a crucial role in ground water infiltration and as such as been assigned high weight followed by the migmatite.

Lineaments are structurally controlled linear or curvilinear features on a map which can be identified from satellite imagery by their relatively linear alignments (Nag et al. 2016). Linear structure can be surface faults, folds, joints/fractures, lithological boundary, or rock contacts which may have been produced during orogenic activities or during various episodes of deformation that affected the basement complex terrain of Nigeria. They are quite significant in ground water prospecting because their presence could lead to an increase in secondary porosity and permeability which are significant in groundwater potential zone mapping. Surface lineaments across the area of research were extracted from band 7 of Landsat 8 data automatically. The lineament density map was then prepared using line density in GIS software and is depicted in Fig $2 \mathrm{f}$. By carefully examining the values obtained, the data were reclassified into five categories: -Very low (0-0.73 km/ km²), Low (0.73-1.47 km/ km²), Moderate (1.47-2.2 km/km²), High (2.2$2.94 \mathrm{~km} / \mathrm{km}^{2}$ ) and Very high (2.94-3.67 km/ km²) (Table 1). Groundwater potential decreases with increasing distance from the lineaments (Arulbalaji et al. 2016), therefore, high weight is assigned for high density and low weight for low density classes. 
Subsurface faults present in the area of study were extracted from first vertical derivative image of the area of study using Oasis Montaj software. Faulting and fracturing within the basement complex terrain of Nigeria causes increased secondary porosity and permeability thereby affecting groundwater potential. Fault proximity refers to how close an area is to faults. It is revealed that the intensity of groundwater potential decreases with increasing distance from these faults. 0 to $199 \mathrm{~m}$ distance represent close proximity while 799 to 999 m represent far proximity (Fig. 2). Therefore, close proximity was ranked higher than far proximity (Table 1).

Drainage density is an important factor in groundwater recharge and accumulation. Drainage network in an area depends on the geology of the area and it provides an important index of infiltration rate. It is an inverse function of permeability which suggests it is an important parameter in the delineation of the groundwater potential zone. Drainage density is obtained by dividing the total length of all the rivers in a drainage basin by total area of the drainage basin (Yeh et al. 2016). High drainage density is a product of less infiltration and as a result has little influence on the groundwater potential of the area. Low drainage density represents high infiltration and hence contributes more to the groundwater potential (Arulbalaji et al. 2016). Drainage density within the study area (Fig 2b) was reclassified and categorized as Very low (450.16-562.7 km/km²), Low (337.62-450.16 km/ km²), Moderate (225.08-337.62 km/ km²), High (112.54$\left.225.08 \mathrm{~km} / \mathrm{km}^{2}\right)$ and Very high (0-112.54 km/ $\left.\mathrm{km}^{2}\right)$. For groundwater potential zonation, high weight assigned for low density and low weight assigned for high density (Table 1).

LULC provides important information on infiltration, soil moisture, groundwater, surface water etc., in addition to providing indication on groundwater requirements. llora and environs exhibit a spectrum of land use categories which include: agricultural land, thick forest, rocks exposures, built-up areas, and water bodies (Fig 2d). The LULC types in the area are delineated from Landsat 8 satellite image by using maximum likelihood classification method. Out of the various class types, farm lands occupy the largest portion of the total landmass followed by thick forest. The LULC classes like forest and agriculture land hold substantially high proportion of water than the built-up land and open land surfaces (Rajaveni et al. 2017). Therefore, high weight is assigned to the thick forest and farm lands while low weight is assigned to the built up and rock exposures (Table 1).

Topography plays an important role in ground water flow and accumulation as well as ground water recharge, topographic factors have a direct effect on flow size and runoff velocity (Kia et al. 2012). Elevation refers to height of an object above sea level. The processed ASTER DEM data of the study area shows that elevation values ranged from 151-352 $\mathrm{m}$. Low elevation is much more significance in ground water development as surface water flows from areas of higher elevation to areas of lower elevation. From the elevation map of the study area (fig. 2c), low elevation values cover a total of $1.4 \%$ while high elevation covers $1 \%$ of the area. Intermediate values make up the remaining $49 \%$. Higher values were assigned to low elevation while lower values were assigned to high elevation. Slope is an important terrain characteristic that gives an insight on the steepness of the ground surface of an area. Slope map provides valuable information on the nature of the geologic and geodynamic processes operating at regional scale of an area (Riley 1999). Surface run - off and rate of infiltration are influenced 
essentially by slope of the surface. Larger slopes produce smaller recharge because the water received from precipitation flows rapidly down a steep slope during rainfall, therefore, it does not have sufficient residence time to infiltrate and recharge the saturated zone (De Reu 2013). Figure $2 \mathrm{~h}$ shows the slope map of the studied area. The slope values were reclassified and categorized into five classes such as flat (0-3.57), gentle (3.57-6.23), medium (6.23-9.28), steep (9.28-13.39) and very steep (13.39-33.8). High weight is assigned to flat and gentle slopes while low weight is assigned for steep and very steep slope (Table 1).

Soil types play a vital role on the amount of water that infiltrates subsurface formations and hence has a high influence on groundwater recharge (De Reu et al. 2013). Soil texture and hydraulic characteristics are the main factors considered for estimation of rate of infiltration. Soil map of the area of research is displayed in Figure $2 \mathrm{~g}$. About $94 \%$ of the area of study is covered by Lixisol/Luvisols -9 soils, while the remaining $6 \%$ is covered by Luvisol-44 (Table 1 ). The details of the soil categories identified in this study can be found in the Center for World Food Studies (SOW-UV) (1997) soil map of Nigeria.

\section{Ground water potential zone and validation}

Within the south western basement complex terrain of llora and environs, it was imperative to delineate the ground water potential zones of the area due to massive water shortages and overreliance on the usage of rainfall and stream water for domestic and agricultural purposes. The ground water potential zones in the area were delineated using AHP technique, which is one of the effective techniques for ground water potential zonation. The eight (8) thematic layers (Elevation, Slope, Soil, Geology, Lineaments density, Fault proximity, Drainage Density, Land use land cover) were used to classify the study area into various groundwater potential zones. Figure 4 shows the groundwater potential zones in the area of study. The output groundwater potential zone map was further classified into five zones for easy understanding, they are: very low, low, moderate, high, and very high. From Table 2, very high zone covers a total of $1.5 \%$ of the total area, high ground water potential zone covers $35.6 \%, 54.8$ by moderate zone, $7.8 \%$ for low and $0.3 \%$ for areas that have a very low groundwater potential.

High ground water potential zones in the study area are typified by low elevation, low slope angles, low drainage densities, high lineament densities, close proximity to faults, forest and farmlands, and presence of fractured and permeable soils. These appears in large part of the area of study apart from the south eastern part of the area of research which was classified as built-up area. In contrast, low ground water potential zones in the research area are typified by high elevation, high slope, built up areas, lack of permeable soils and fractured rocks, farness to faults, high drainage density, and little or no surface lineaments. Moderate ground water potential zones dominate the area of research and the study area can be classified as a moderate to high ground water potential area.

The ground water potential zones delineated in this research were correlated with static water levels and well yield data from observation wells across the study area. It is revealed that wells sited in the very high and high groundwater potential zones have static water level values in the range of 6 to 7 and water yielding capacity in the range of 70-120 liters per minute (LPM), wells located in moderate groundwater 
potential zones have static water level values that ranged from 4 to 5 and water yielding capacity in the range of 30 to 70 LPM, while wells sited in very low and low groundwater potential zones have static water level values that ranged from 1 to 3 and water yielding capacity within 5 to 30 LPM. llora town recorded low static water levels together with low well yield and therefore fell within the low and very low areas of the ground water potential zone map. Also, majority of the farmland in the area of study have moderate to high static water levels and well yield values and as such displayed moderate to high ground water potential.

From the thirty six (36) observatory wells, thirty three (33) of the obtained values agree with the ground water potential zone map of Ilora while the other three (L19, L30, L32) which fell within high potential zone region of the map have moderate ground water potential values.

In order to access the accuracy of the ground water potential zone map produced in the study, the location of the observatory wells used in validation were correlated with the produced ground water potential zone map generated by AHP technique. The ground water potential map was reclassified into three where very low and low potentials are classified as low and assigned an accurate value of one (1), moderate as moderate (2), and high and very high as high with an accurate value of three (3). The observed well data were also reclassified into three; with 1-3 static water levels and 5 to 30 LPM classified as one (1), 4-5 static water levels and $30-70$ LPM classified as two (2), while 6 -7 static water levels and $70-120$ LPM were categorized as three (3). Table 4 shows the error matrix result of the correlation and the accuracy between the ground water potential map and the observatory wells can be calculated to be $89 \%$ which shows high correlation. This further confirms the relevance of AHP technique in ground water zonation investigations.

\section{Conclusion}

A proper evaluation of the groundwater potential of an area is very vital especially in the aspect of planning and sustainable development. Such information is priceless during the design and implementation of structures that can be used to make portable water available in abundance for domestic and agricultural usages.

This study attempts to delineate the groundwater potential zones within llora and environs using a combination of GIS, Remote sensing, and Geophysical techniques. Eight thematic layer maps such as Land Use/Land Cover, Geology, Lineament Density, Slope, Drainage Density, Elevation, fault proximity and Soil were used in this study to map out the groundwater potential zones in the research area using AHP.

From the generated Groundwater Potential Zone map, the research area was classified into five groundwater potential zones namely; Very high, High, Moderate, Low and Very low. Very high and high groundwater potential zones are predominantly located within the central part of the study area which are occupied by farmland and thick forest while very poor dominates the south eastern part of the area. The low and very low zones are the densely populated part of the study area. Moderate groundwater potential zone is present in all part of the area, covering a total of $54.8 \%$ of the area of study. Very high and high 
groundwater potential zone covered a total of $37.1 \%$ while low and very low covered approximately 1.1 $\%$.

The delineated groundwater potential zones map of the area of study was further cross-validated with observatpry well data collected from the area. The data included static water levels and well yield data. The data plotted well on the various zones on the ground water potential zone map and accuracy assessment shows a high correlation value of $89 \%$. Therefore, the groundwater potential zone map produced in this research will assist decision makers in proper planning and management of groundwater resources so as to efficiently put a lasting end to the current scarcity of water that is presently affecting llora and environs. It will be a huge plus for borehole/well drillers if groundwater potential maps such as the one in this study are consulted before embarking on drilling activities in order to save capital and valuable exploration time.

\section{Declarations}

\section{Acknowledgements}

The authors are thankful to the different government and non-governmental organizations that made available the various useful data for this research. The authors are also thankful to the anonymous reviewers for their constructive comments on how to improve the manuscript.

\section{Conflicts of interest}

The authors have no conflicts of interest to declare that are relevant to the content of this article.

\section{Funding}

No grants, funds, or other support was received.

\section{References}

Abdelkareem, M., Akrby, A., Fakhry, M., Mostafa, M., (2018). Using of Remote Sensing and Aeromagnetic Data for Predicting Potential Areas of Hydrothermal Mineral Deposits in the Central East-ern Desert of Egypt. Journal of Remote sensing. 7(1), pp.1 - 13

Al-Gharni M.A., (2005). Application of Magnetic and Electrical Geophysical Methods in the Exploration of Groundwater Resources of Wadi Malakan, Saudi Arabia. Journal of King Abdulaziz University: Earth Science. 16:67-93

Arulbalaji, P., and Gurugnanam, B., (2016). An Integrated Study to Assess the Groundwater Potential Zone Using Geospatial Tool in Salem District, South India. J. Hydrogeol. Hydrol. Eng. 
Badamasi, S., Sawa, B. A, and Garba, M. L. (2016). Groundwater Potential Zones Mapping Using Remote Sensing and Geographic Information System Techniques (GIS) in Zaria, Kaduna State, Nigeria. American Scientific Research Journal for Engineering, Technology, and Sciences (ASRJETS), 24:51-62

Bayowa O.G., Olorunfemi M.O., Akinluyi F.O., and Ademilua O.L, (2014). Integration of Hydrogeophysical and Remote Sensing Data in the Assessment of Groundwater. Ife Journal of Science.

Boeckh, E. (1992). "An Exploration Strategy for Higher-Yield Boreholes in the West African Crystalline Basement.". In The Hydrogeology of Crystalline Basement Aquifers in Africa. Wright and Burgess Ed. UK : Geological Society Special Publication No 66, pp. 87-100.

Congalton, R.G., 1991. A review of assessing the accuracy of classification of remotely sensed data. Remote Sens. Environ. 37 (1), 35-46. https://doi.org/10.1016/0034- 4257(91)90048-B.

De Reu, J. (2013) Application of the topographic position index to heterogeneous landscapes. Geomorphology, 186:39-49.

Dobrin, M.B., Savit, C.H., (1988). Introduction to geophysical prospecting. McGraw-Hill Book Co, Singapore Doke A.B., Zolekar R.B., Patel, H., Das, S., (2021). Geospatial mapping of groundwater potential zones using multi-criteria decision-making AHP approach in a hardrock basaltic terrain in India. Ecological Indicators. 127:1-16

Eaton T. T., Anderson M. P., Bradbury K. R. (2007). Fracture control of ground water flow and water chemistry in a rock aquitard. Ground Water. 45(5):601-15. doi: 10.1111/j.1745-6584.2007.

Erakhrumen, A. A. (2008). Influence of specific gravity on wood species selection for Agroforestry in some local government areas of Oyo State, Nigeria. African Journal of Agricultural Research.3(2),134-139.

Fashae, O.A.. Tijani, M.N., Talabi, A.O., Adedeji O.I., (2014). Delineation of groundwater potential zones in the crystalline basement terrain of SW-Nigeria: An Integrated GIS and Remote sensing approach. Applied Water Science. 4(1), 19-38.

Hazell, J.R.T., Cratchley, R., and Jones, C.R.C. (1992). "The Hydrogeology of Crystalline Aquifers in Northern Nigeria and Geophysical Techniques Used in Their Exploration." In The Hydrogeology of Crystalline Basement Aquifers in Africa. Wright and Burgess Ed. UK: Geological Society Special Publication No 66, 1992, pp. 155182.

Hussein, A. A., Govindu, V., Nigusse, A. G. M. (2017). Evaluation of groundwater potential using geospatial techniques Appl. Water Sci., 7 (5) 2447-246.

Loke, M .H., (2013). Tutorial : 2-D and 3-D electrical imaging surveys. 
Muthamilselvan, A., Srimadhi, K., Nandhini, R., Pavithra, P., Balamurugan, T. and Vasuki, V., (2017). Spatial Confirmation of Major Lineament and Groundwater Exploration using Ground Magnetic Method near Mecheri Village, Salem District of Tamil Nadu, India. Journal of Geology \& Geophysics. 6:1, pp. 2-10

Nampak, H., Pradhan, B., Manap, M.A., 2014. Application of GIS-based data-driven evidential belief function model to predict groundwater potential zonation. J. Hydrol. (Amst) 513, 283-300.

Obaje, N.G., 2009. Geology and Mineral Resources of

Nigeria. Springer, Berlin, Heidelberg, Vol. 120.

Obaje, N.G., 2009. Geology and Mineral Resources of

Nigeria. Springer, Berlin, Heidelberg, Vol. 120.

Obaje, N.G., 2009. Geology and Mineral Resources of

Nigeria. Springer, Berlin, Heidelberg, Vol. 120

Obaje, N.G., 2009. Geology and Mineral Resources of Nigeria. Springer, Berlin, Heidelberg, Vol. 120.

Offodile, M.E. (2002). Groundwater Study and development in Nigeria. Mecon and Geology and Engineering Services Limited Jos, Nigeria.

Ogundele, A. T., Oladapo, O. S., Aweto, A. O. (2012). Effects of charcoal production on soil in Kilnsites in Ibarapa Area, South-western Nigeria. Ethiopian Journal of Environmental Studies and Management 5(3), 296-304

Olasehinde, P. I. (1999). An integrated geological and geophysical exploration for groundwater in the basement complex of west central Nigeria. Water resources, 10, 46-49.

Olorunfemi, M. O., and Fasuyi, S. A. (1993). Aquifer Types and the geoelectric/Hydrogeologic Characteristics of Part of the Central Basement Terrain of Nigeria (Niger State). Journal of African Earth Sciences 16(3):309-317.

Olorunniwo, M. A. and Olorunfemi, M. O. (1987). Geophysical Investigations for Groundwater in Precambrian Terrains: a case study from Ikare, Southwestern Nigeria. Journal of African Earth Sciences, $6(6): 787-796$

Oni, A.G., Eniola, P.J., Olorunfemi, M.O., Okunubi, M.O., Osotuyi, G.A., (2020). The magnetic method as a tool in groundwater investigation in a basement complex terrain: Modomo Southwest Nigeria as a case study. Applied Water Science 10:190, pp.1-18

Rahmati, O., Samani, A.N., Mahdavi, M., Pourghasemi, H.R., Zeinivand, H., 2015. Groundwater potential mapping at Kurdistan region of Iran using analytic hierarchy

Page $12 / 20$ 
process and GIS. Arab. J. Geosci. 8 (9), 7059-7071.

Rajaveni, S. P., Brindha, K., and Elango L. (2017). Geological and geomorphological controls on groundwater occurrence in a hard rock region. Appl. Water Sci. 7:1377-1389.

Riley, S. J. (1999). Index that quantifies topographic heterogeneity. Intermt. J. Sci., 5:23-27.

Saaty, T. L. (1990). Decision making for leaders: the analytic hierarchy process for decisions in a complex world (RWS publications).

Senanayake, I. P., Dissanayake, D. M. D. O. K., Mayadunna, B. B., Weerasekera, W. L., (2015). An approach to delineate groundwater recharge potential sites in Ambalantota, Sri Lanka using GIS techniques, Geoscience Frontiers, doi: 10.1016/j.gsf.2015.03.002.

Singhal, B. B. S. and Gupta, R. P. (1999). Applied hydrogeology of fractured rocks. The Netherlands, Kluwer Academic Publ. 401 pp, https:// doi.org/10.1007/978-90-481-8799-7.

Yeh, H.F., Cheng, Y.S., Lin, H.I., Lee, C.H., 2016. Mapping groundwater recharge potential zone using a GIS approach in Hualian River. Taiwan. Sust. Environ. Res. 26 (1), 33-43

\section{Tables}

Table 1: Calibration and Weight evaluation for ground water potential 


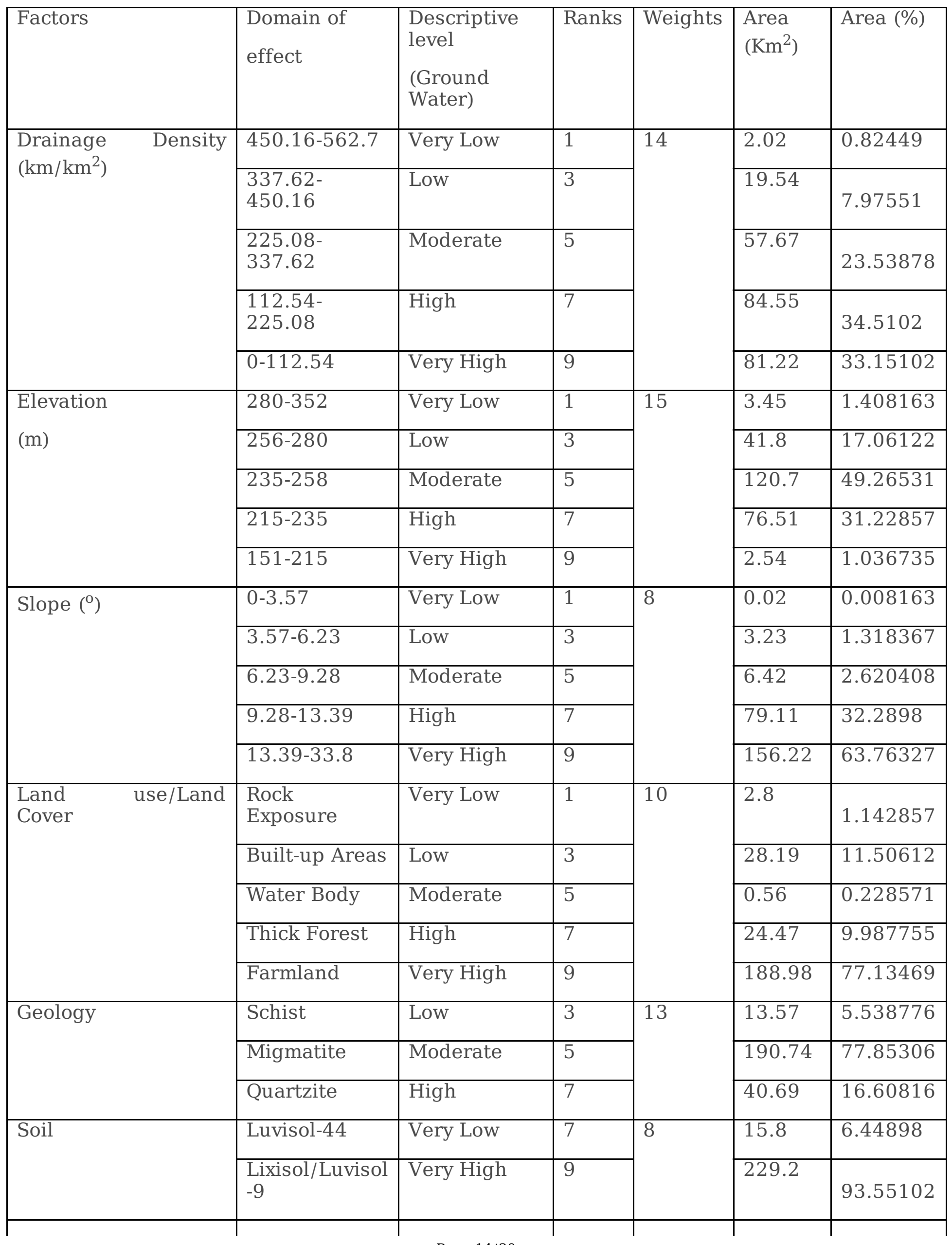




\begin{tabular}{|c|c|c|c|c|c|c|}
\hline \multirow[t]{5}{*}{ Lineament $\left(\mathrm{km} / \mathrm{km}^{2}\right)$} & $0-0.73$ & Very Low & 1 & \multirow[t]{5}{*}{15} & 165.07 & 67.37551 \\
\hline & $0.73-1.47$ & Low & 3 & & 64.18 & 26.19592 \\
\hline & $1.47-2.2$ & Moderate & 5 & & 12.23 & 4.991837 \\
\hline & $2.2-2.94$ & High & 7 & & 3.1 & 1.265306 \\
\hline & $2.94-3.67$ & Very High & 9 & & 0.42 & 0.171429 \\
\hline \multirow[t]{5}{*}{ Fault Proximity (m) } & 791-999 & Very Low & 1 & \multirow[t]{5}{*}{17} & 91.01 & 37.14694 \\
\hline & $591-791$ & Low & 3 & & 35.42 & 14.45714 \\
\hline & $391-591$ & Moderate & 5 & & 41.32 & 16.86531 \\
\hline & $199-391$ & High & 7 & & 40.93 & 16.70612 \\
\hline & $0-199$ & Very High & 9 & & 36.32 & 14.82449 \\
\hline
\end{tabular}

Table 2: Groundwater potential zones and their areal coverage

\begin{tabular}{|l|l|l|}
\hline Ground Water Potential & Area Covered (Km2) & \% Covered \\
\hline Very Low & 0.75 & 0.3 \\
\hline Low & 19.12 & 7.8 \\
\hline Moderate & 134.21 & 54.8 \\
\hline High & 87.21 & 35.6 \\
\hline Very High & 3.71 & 1.5 \\
\hline
\end{tabular}

Table 3: Location and characteristics of the observation well 


\begin{tabular}{|c|c|c|c|c|}
\hline Location Number & $\mathrm{X}$ & $\mathrm{Y}$ & Static Water Level & Water Yield (LPM) \\
\hline L1 & 3.903313 & \begin{tabular}{|l}
7.788107 \\
\end{tabular} & 2.54 & $5-30$ \\
\hline $\mathrm{L} 2$ & 3.90864 & \begin{tabular}{|l|}
7.793838 \\
\end{tabular} & 1.87 & $5-30$ \\
\hline L3 & 3.890501 & 7.803152 & 2.98 & $5-30$ \\
\hline L4 & 3.897147 & 7.804463 & 3.21 & $5-30$ \\
\hline L5 & 3.897157 & \begin{tabular}{|l|}
7.80888 \\
\end{tabular} & 1.97 & $5-30$ \\
\hline L6 & 3.908658 & 7.80223 & 3.55 & $5-30$ \\
\hline L7 & 3.914901 & 7.821651 & 3.21 & $5-30$ \\
\hline L8 & 3.903749 & 7.785014 & 2.88 & $5-30$ \\
\hline L9 & 3.894668 & \begin{tabular}{|l}
7.887507 \\
\end{tabular} & 4.67 & $30-70$ \\
\hline L10 & 3.898229 & \begin{tabular}{|l|}
7.89545 \\
\end{tabular} & 4.9 & $30-70$ \\
\hline L11 & 3.87914 & \begin{tabular}{|l}
7.876497 \\
\end{tabular} & 4.68 & $30-70$ \\
\hline L12 & 3.830706 & 7.801065 & 5.22 & $30-70$ \\
\hline L13 & 3.824502 & 7.79931 & 4.99 & $30-70$ \\
\hline L14 & 3.851737 & 7.906589 & 4.88 & $30-70$ \\
\hline L15 & 3.851711 & \begin{tabular}{|l|}
7.89378 \\
\end{tabular} & 5.25 & $30-70$ \\
\hline L16 & 3.831746 & 7.878802 & 4.66 & $30-70$ \\
\hline L17 & 3.884469 & \begin{tabular}{|l}
7.88267 \\
\end{tabular} & 5.2 & $30-70$ \\
\hline L18 & 3.869012 & 7.90567 & 5.18 & $30-70$ \\
\hline L19 & 3.816967 & 7.796233 & 5.68 & $30-70$ \\
\hline L20 & 3.890167 & 7.854389 & 6.75 & $70-120$ \\
\hline L21 & 3.910534 & 7.85037 & 6.08 & $70-120$ \\
\hline L22 & 3.887083 & 7.862346 & 5.33 & $30-70$ \\
\hline $\mathrm{L} 23$ & 3.833909 & 7.852738 & 5.02 & $30-70$ \\
\hline L24 & 3.847652 & 7.858452 & 5.18 & $30-70$ \\
\hline L25 & 3.855217 & 7.875222 & 4.62 & $30-70$ \\
\hline L26 & 3.846333 & \begin{tabular}{|l|}
7.863314 \\
\end{tabular} & 4.49 & $30-70$ \\
\hline L27 & 3.836001 & \begin{tabular}{|l}
7.791337 \\
\end{tabular} & 7.14 & $70-120$ \\
\hline L28 & 3.840438 & \begin{tabular}{|l}
7.795303 \\
\end{tabular} & 7.65 & $70-120$ \\
\hline L29 & 3.850187 & \begin{tabular}{|l|}
7.797934 \\
\end{tabular} & 4.01 & $30-70$ \\
\hline L30 & 3.862694 & \begin{tabular}{|l|}
7.849588 \\
\end{tabular} & 4.76 & $30-70$ \\
\hline L31 & 3.826286 & 7.805491 & 5.19 & $30-70$ \\
\hline L32 & 3.843141 & \begin{tabular}{|l}
7.817825 \\
\end{tabular} & 4.62 & $30-70$ \\
\hline L33 & 3.845408 & 7.843881 & 7.89 & $70-120$ \\
\hline L34 & 3.867989 & \begin{tabular}{|l|}
7.839418 \\
\end{tabular} & 5.08 & $30-70$ \\
\hline L35 & 3.85646 & 7.833258 & 5.63 & $30-70$ \\
\hline L36 & 3.874228 & 7.857956 & 5.12 & $30-70$ \\
\hline
\end{tabular}

\section{Table 4: Error Matrix}

\begin{tabular}{|l|l|l|l|l|}
\hline ID & Accuracy & True1 & True2 & True3 \\
\hline 1 & 1 & 8 & 0 & 0 \\
\hline 2 & 2 & 0 & 7 & 2 \\
\hline 3 & 3 & 0 & 2 & 17 \\
\hline
\end{tabular}


Figures
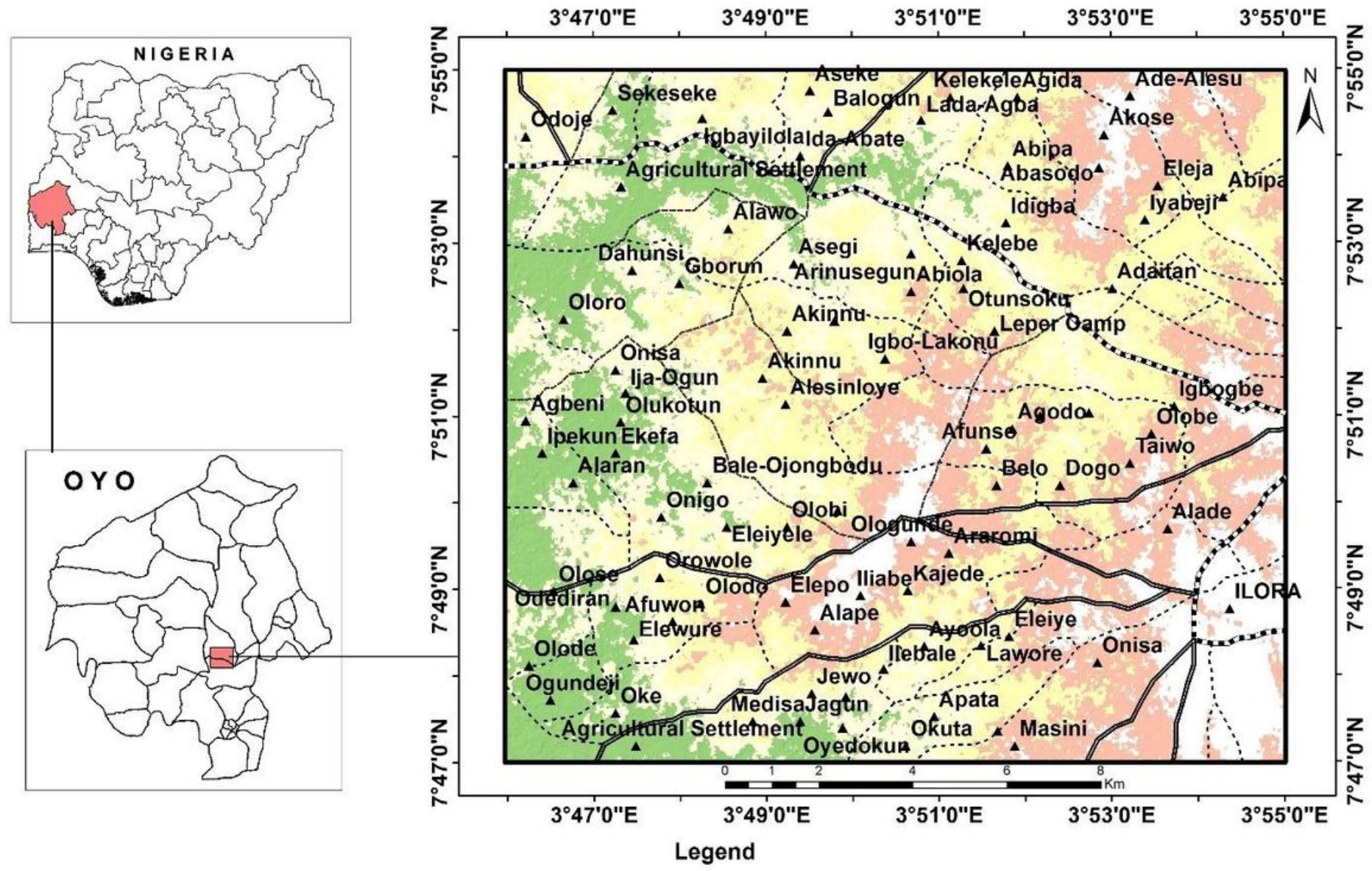

A Settlement ...... Minor Footpath ----- Major Footpath

= Minor Road ..... Major Road $\square$ Study Area Boundary

Figure 1

Location map of llora and environs 


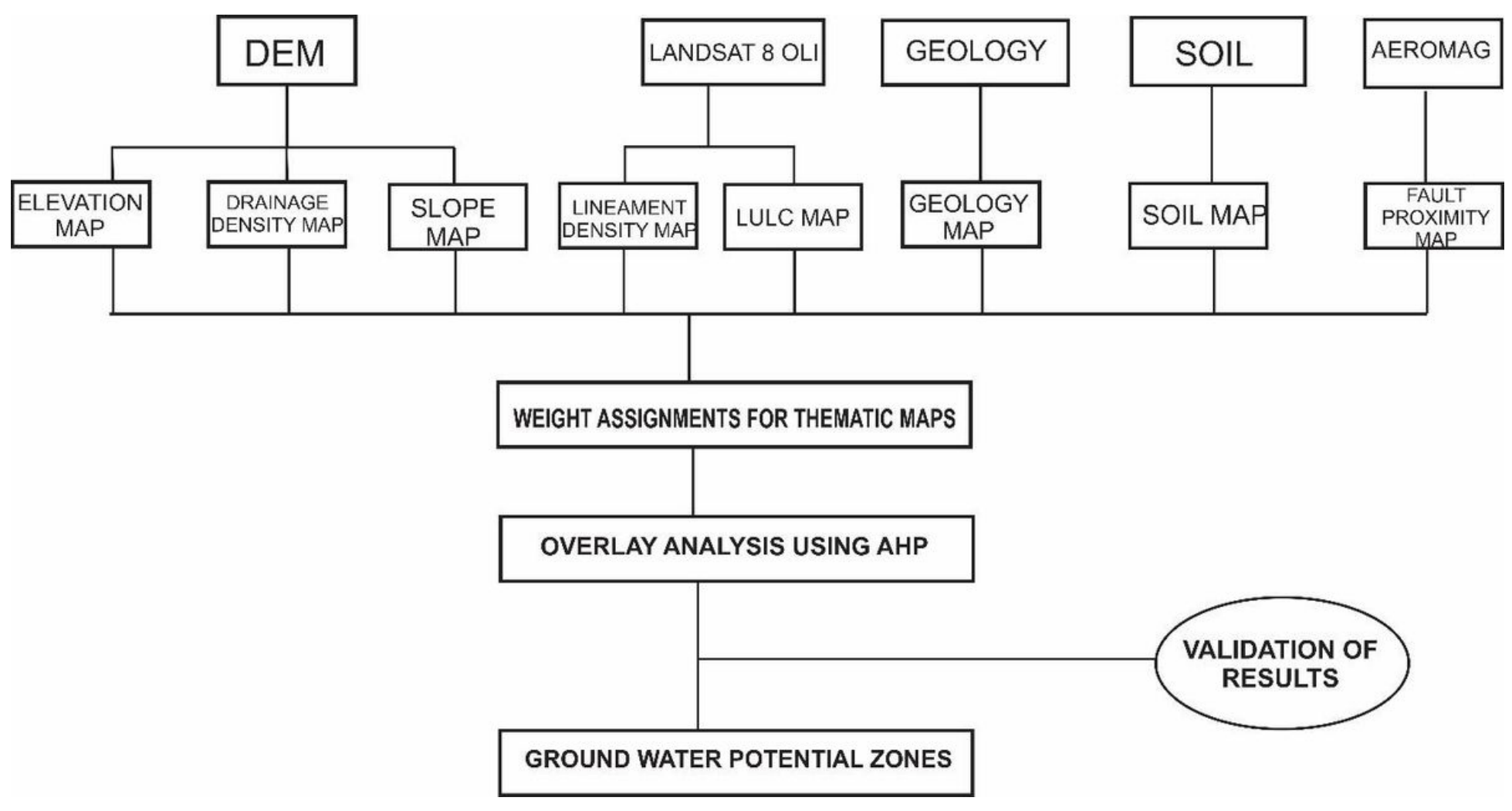

Figure 2

Flow chart of method used for groundwater potential zone mapping of Ilora and environs 

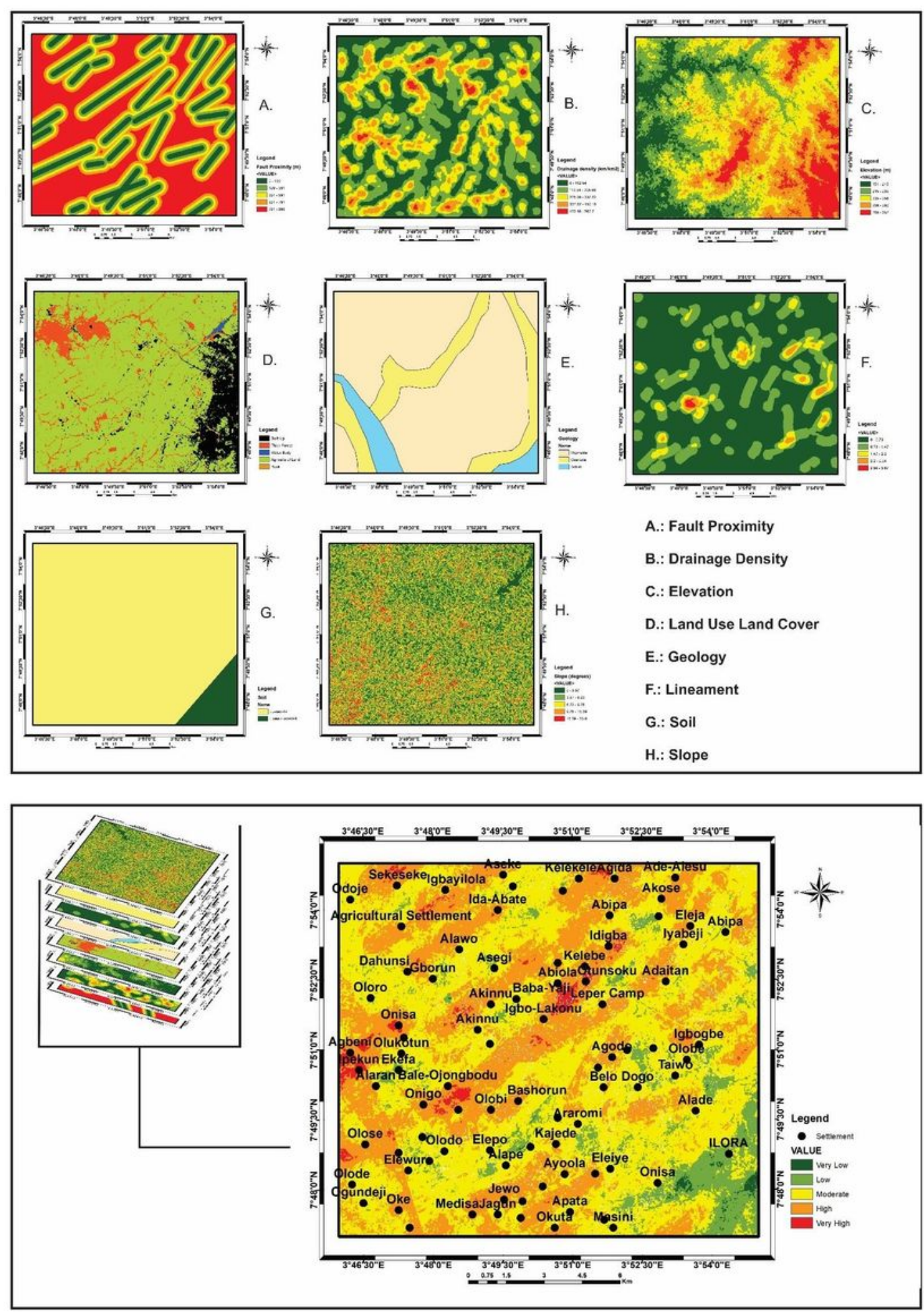

\section{Figure 3}

Thematic maps used for groundwater potential zone mapping. Groundwater potential zone delineation. Groundwater potential zone map of the llora and environs 


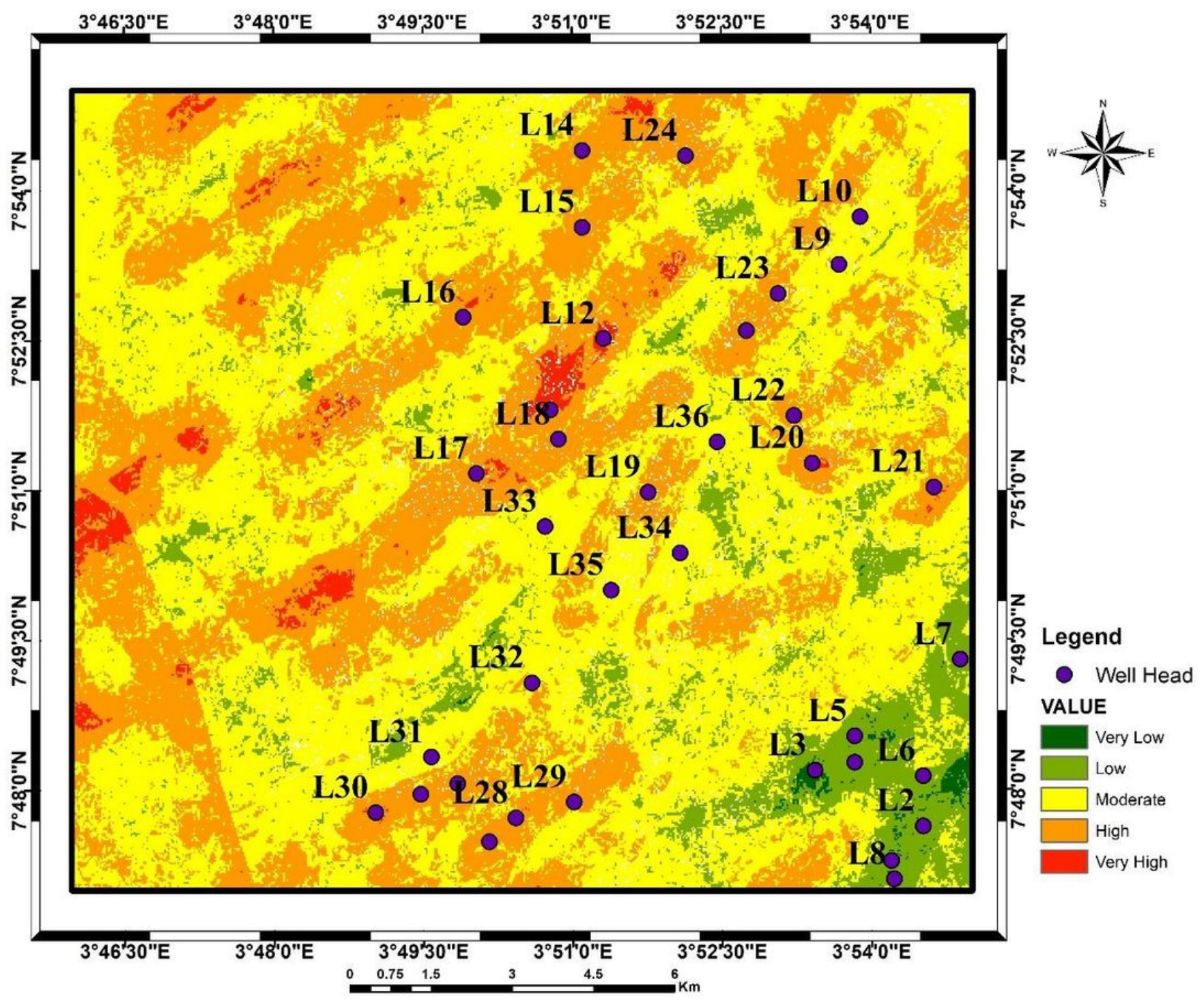

Figure 4

Ground water potential zones with Observatory well locations 